The Impact of Investors' Excessive Biased Expectations ...

Sally Mahmoud Hashem Shams

\title{
The Impact of Investors' Excessive Biased Expectations on Opaque Financial Reporting
}

Sally Mahmoud Hashem Shams

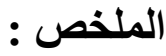

يهدف هذا البحث الى دراسة أثر التحيز فى توقعات المستثرين على غموض التقارير

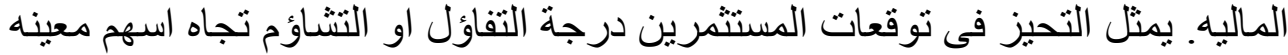

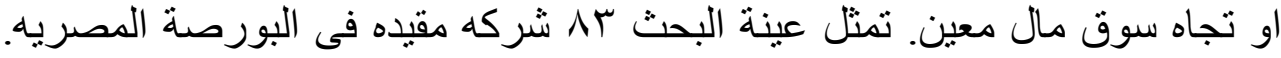

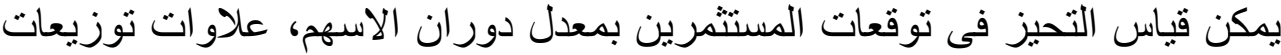

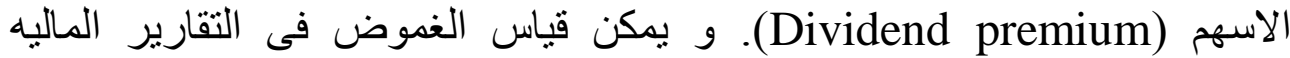

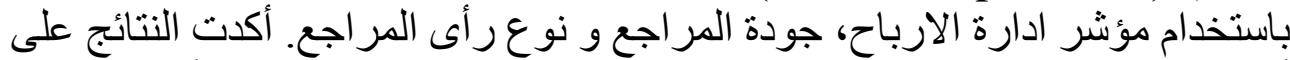

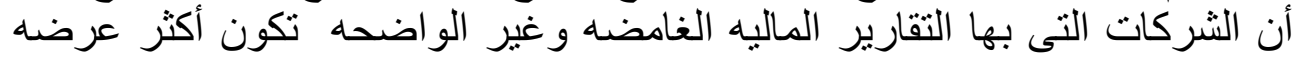
لقرار ات المسثمرين المتحيزه. بهئر

\section{Abstract:}

This research investigates the influence of investors' biased expectations on the opacity of financial reporting. Excessive biased expectations reflect optimism or pessimism of investors toward certain security or a particular financial market. Sample size consists of 83 companies listed in the Egyptian stock exchange. Three measures can be used to measure investors' biased expectations: Share Turnover, E Share, and dividend premium. Three measures can be used to measure financial reporting opacity: earnings management, quality of auditors and the type of audit opinion. Results imply that, companies with greater opaque financial reporting environment are more affected by excessive biased expectations of investors.

\section{A.Introduction:}

The importance of information veracity in valuing securities has long been recognized in recent years. It is clear that, the main purpose of the accounting system is to provide users either 
The Impact of Investors' Excessive Biased Expectations ...

Sally Mahmoud Hashem Shams

internally or externally with the necessary information helping them to take accurate investing decision. Financial information is relevant if it is capable of making a difference in users' decision making. That is, if it has predictive or confirmatory value, or both. This information can be perfectly faithful representation if it is complete, neutral and free from errors.

There is a growing debate concerning opacity of financial information environment. Which represent phenomena of uncertainty and unclear information that face financial statements' users and expose them to many risks and which in return affect firm value and reduce firm performance and produce fertile environment for opportunistic behaviors by managers and other insiders.

This study aims to contribute to the existing literature by investigating the impact of investors' biased expectations on the opaque financial information environment.

\section{2-Investors' Excessive Biased Expectations:}

Investors' excessive biased expectations can be considered as investors' attitude toward a particular security or a certain financial market. It is the feeling or tone of a market, or its crowd psychology, as revealed through the activity and price movement of the stocks traded in that market. For example, rising stock prices refer to bullish market sentiment or a case of investor optimism and represent higher investor sentiment levels, while falling prices may indicate a bearish market sentiment or a case of investor pessimism and represent lower levels of investor sentiment.

The study of (Cahan et al; 2013) shed light on the optimism and pessimism embedded in news items about the firm. Using media sentiment as a firm-specific measure of investor sentiment, they 
The Impact of Investors' Excessive Biased Expectations ...

Sally Mahmoud Hashem Shams

contended that, investors overreact to positive earnings surprises when firm-specific media sentiment is positive. On the other hand, they overreact to negative earnings surprises when firmspecific media sentiment is negative. They also found that, after controlling for market-wide investor sentiment, positive firmspecific media sentiment increases the market's reaction to good unexpected earnings and decreases the market's reaction to bad unexpected earnings, while negative firm-specific media sentiment increases the reaction to bad unexpected earnings and decreases the markets' reaction to good earnings. These results are driven by firms that have higher valuation uncertainty and hard to value firms. This suggests that the tone of news items may lead to stock misvaluation (mispricing). Further, bad earnings news is more likely to be affected by media sentiment than good earning news.

Sentiment analyses concentrate on determining agents' opinion on a particular topic. Opinions are usually classified as positive or negative often with some stratification between the two. This can be done numerically or categorically. When division is categorical, it usually distinguishes between positive, negative and sometimes neutral sentiment, otherwise the numerical classification falls between positive and negative.

These classifications can be used to define and aggregate the sentiment of a large number of investors concerning stock price prediction. In which sentiment can be easily checked for correlations between public opinion and public behavior (Dickinson and $\mathrm{Hu}, 2015$ ).

When investors are optimistic, or when they have high tendency to speculate, they are willing to demand the extreme stocks of both high growth and distressed firms. On the other hand, in optimism, or when investors' tendency to speculate is low, they 
The Impact of Investors' Excessive Biased Expectations ...

Sally Mahmoud Hashem Shams

avoid extreme stocks. Further, investors are willing to hold young and high volatile stocks when sentiment is positive and older and low volatile stocks when sentiment is negative. This is consistent with the theoretical prediction that both rapidly growing firms and extremely distressed firms are difficult to value and harder to arbitrage and tend to be more sensitive to sentiment changes.

\section{3-Opaque Financial Reporting}

An opaque environment is more likely to facilitate a managers' use of information advantage to try to shift wealth from investors to themselves by attaining higher levels of compensation. In contrary, when opacity decreases (i.e. transparency increases) it facilitates shareholder monitoring and mitigates managerial manipulation.

Firms with higher sensitivity to investor sentiment tend to be relatively opaque. Particularly, if the available information concerning a certain stocks is difficult to interpret, it will be difficult for economic agents to value these securities and it will be challengeable to resolve the veracity of the disclosed information. Consequently, it will be difficult for arbitrageurs and speculators to measure and capitalize on mispricing in these securities.

Baker and Wurgler, 2006 suggested that small firms are more likely be more opaque, harder to value, and thus will be most prone to investor sentiment swings.

Berger \& Turtle, 2012 investigated the cross-sectional effect of investor sentiment on firms with different opacity levels using a variety of risk models. They found a significant and strong relation between opaque firms and investor sentiment. Particularly, stocks that are more likely to be affected by 
The Impact of Investors' Excessive Biased Expectations ...

Sally Mahmoud Hashem Shams

sentiment waves are small, young, volatile, consist of relatively intangible assets, and in general expose opaque characteristics. They found evidence that portfolios of opaque firms exhibit contradicting conditional performance. Portfolios of opaque firms constituted after periods of high sentiment display poor marginal performance and opaque firms display strong positive performance after periods of low sentiment. In contrast, the portfolio of translucent firms displays little variation in conditional alpha across all sentiment levels. Specifically, investor sentiment sensitivities increase directly with different opacity measures.

A further and likely important determinant of the quality of accounting information is the adoption of IFRS (International Financial Reporting Standards).

Houqea, et al; 2012 indicated that IFRS increase earnings quality because firms become under pressure to provide a true and adequate information and mitigate managers' opportunistic behaviors and thus improve reporting quality. Improvement of accounting and earnings quality depends on at least two factors: high quality accounting standards and country's overall investor protection level.

\section{4-Sources of Financial Reporting Opacity and Complexity:}

Complexity of companies' financial statements might be resulted by many factors, some of these factors are external to the company, such as accounting standards designation that force more information disclosures, and others are consequences of companies' operating and financial decisions. Factors that may lead to financial complexity (opacity) include the following:

A. Accounting Standards. The design of accounting standards has two key problems; the first is inconsistency. For 
The Impact of Investors' Excessive Biased Expectations ...

Sally Mahmoud Hashem Shams

instance, the accounting rules developed for the industrial age seems to be ineffective in the information age. Research and development expenses at technology firms are treated as operating instead of capital expenses, operating leases are not considered financial expenses and employee options are not treated as part of compensation expense. Therefore, company's choices regarding these items might results in greater variations in how earnings are measured. The second problem stems from how companies account for its income and expenses which may affect investors' exposure to uncertainties and risk.

B. Aggressive accounting practices. Although it is legal, it can inflate firm's reported earnings. Increased disclosure might have unintended and negative consequences. The financial reports might be bloated to include often petty details.

C. Companies entering into new markets or businesses. How these businesses are structured affect the resulting complexity. For an example, keeping each business separate enable firm to easily valuation than firms which collect all the businesses into one entity. In some times, company may create subsidiaries for each business while holding less than $100 \%$ of these subsidiaries.

\section{Proliferation of financing choices and newly different} ways of raising funds. Companies can raise its funds using convertibles, warrants, and other hybrids. A new category of funding that called quasi-equity, representing hybrid securities, it consist of equity part and debt part, it now plays a prominent role in many statements of financial position. Company's innovation of keeping debt in their books may result in additional complexity.

\section{5-Negative Consequences of Opaque Financial Reporting}

Opacity of financial reporting has many different negative consequences on financial market. An important consequence is 
The Impact of Investors' Excessive Biased Expectations ...

Sally Mahmoud Hashem Shams

corruption that may have a bad and negative effect on investment and economic growth. Another consequence is imbalance between return and risk. In this case, naïve individuals may be exposed to more risks and low return and vise verse, so, the wealth will be on the hands of few and no earn is produced (Salteh \& Babazadeh, 2012).

\section{5-10pacity and Crash Risk}

Through analyzing the dynamics of opacity and crash risk, it is obvious that countries with opaque markets have higher likelihood of crash risks.

Several financial studies have related the quality of information disclosure to stock price dynamics and some recent studies pertains firm's information opacity to the second moment of the stock returns' distribution, which express a positive relationship between opacity and stock price crashes. The common understanding is that firms associated with lowered transparency levels are more likely to withhold bad news and investors tend to be more prone to "information herding behavior", which in return cause stock price crashes when cumulative negative information suddenly becomes publicly available in the market.

If managers hide negative information for an extended period, such negative information becomes incrementally stockpiled. After a specific tipping point, it will be very expensive and even impossible for managers to continuously withhold bad news. Thus, stockpiled bad news exit all at once, causing stock prices crashes.

There is a growing debate and a significant research interests concerning the relation between synchronicity or low idiosyncratic volatility and more transparency or more opacity of firm-specific information in the finance and accounting literature. 
The Impact of Investors' Excessive Biased Expectations ...

Sally Mahmoud Hashem Shams

Prior studies found contradicting views concerning this point.

Bad information environment expose higher volatility and low $\mathrm{R} 2$, may be an indicator of stock price informativeness.

Hutton et al; 2009 investigated the relation between stock return synchronicity with the market and financial statements opacity. He found evidence of a positive relationship between opacity, proxied by earnings management, and synchronicity.

Synchronicity is measured by $\mathrm{R} 2$ which regress the firm's stock returns on the market returns. Therefore, higher R2 implies higher synchronicity. In addition, they conclude that opaque firms are more prone to stock price crashes.

\section{5-20pacity, Corruption, and Accounting Quality}

Corruption exists in all communities; it has assertive negative impact on investment, growth and the political behavior. It means the misuse of public or business office for private benefits.

People's behavior depends heavily on their cultural background. Investors may analyze information differently because of their different cultural backgrounds. It also affects investors' exposure to sentiment and asset evaluation. Therefore, as financial markets expand internationally, it becomes important to take cultural influences into consideration (Bank and Brustbauer, 2014).

In a world where the managerial and political official actions as well as the resulting consequences are not fully observable to different stakeholders, those officials have motivations to appropriate parts of the stakeholder' income. This behavior is called rent seeking behavior, which needs to be as "hidden" as possible and depends on the information quality provided to stakeholders and available in the capital markets. 
The Impact of Investors' Excessive Biased Expectations ...

Sally Mahmoud Hashem Shams

The common consequences of corruption are the disconcerting of growth and investment, constraining the consolidation of democratic institutions and open market economies, as well as its impact on the quality of accounting which is more important and linked to this field of study.

Prior literature indicated a positive association between the increase of corruption level and the level of earnings opacity.

As the quality of financial reporting increases, accountability or monitoring the activities of managers and political officials rises, which in return decrease the opportunities for rent appropriations. Accountability is based on the utilization of performance evaluation numbers derived from a good quality of accounting system .

Since, rent seeking behaviors reflect the need for more flexible accountability or a lower quality accounting system as a way to manufacture higher levels of corruption backgrounds and to camouflage its actions and consequences. Hence, it may be expected that, earnings opacity, as a measure of the low accounting quality, predisposes to the climate of corruption.

On another hand, Corruption provides an unmoral atmosphere that compels individuals to accept the appropriation of other people's income. The lower ethical levels, resulting from corruption, outreach other activities even the collection and dissemination of information in general and accounting information in particular.

\section{6-The Importance of Transparency in the Financial System:}

Indeed, transparency is important for well-functioning markets in general, and particularly for financial markets.

Great effort could be done to enhance the significant aspects of 
The Impact of Investors' Excessive Biased Expectations ...

Sally Mahmoud Hashem Shams

corporate transparency and disclosure universally as a way to achieve greater global capital efficiency.

Generally, transparency is the reveal or disclosure of all information that guarantee the proper institutions' accountability to their different dealers such as boards, investors, shareholders, regulators and stakeholders.

A fundamental feature of the information environment is corporate transparency, defined as widespread availability of relevant, reliable information about the periodic performance, financial position, investment opportunities, governance, value, and risk of publicly traded firms (Bushman \& Smith, 2003).

Corporate transparency measures fall into three categories:

1- Measures of corporate reporting quality, including the intensity, measurement principles, timeliness, and credibility of disclosures or audit quality.

2- Measures of the intensity of private information acquisition, including analyst following, and the prevalence of pooled investment schemes and of insider trading activities.

3- Measures of the quality of information dissemination, including the penetration and private versus state ownership of the media ( Bushman \& Smith, 2003).

Transparency benefits financial systems in at least three ways (GEBI, 2011):

1- Fighting fraud and corruption.

2- Improving market efficiency by enabling price discovery, disclosing hidden costs and, ensuring fairer market conditions. 
The Impact of Investors' Excessive Biased Expectations ...

Sally Mahmoud Hashem Shams

3- Allowing investor protection through reducing information asymmetry and providing improved risk analysis linked to financial products.

Greater transparency leads to higher supervision level, decrease financing cost and lower risk profile. Disclosure of private information decrease incentives to compete on spreads. Therefore, increasing transparency improve companies performance.

Other extreme of research, consider transparency as a new opacity. (Bardley, 2011) stated that many actors constructing financial regulation in the wake of the global financial crisis era have an adherence to transparency. However, transparency in financial regulation is undermined because the information disclosed is simultaneously limited or excessive .

On one hand, the communication is limited: transnational standard setters publish their releases in certain languages, or only in English language. Some institutions publish the full text of responses to consultations whereas others allocate and condense responses inaccurately. In other words, transparency might be limited because much effort are still be needed by policy makers and regulators, who are responsible for developing the rules of financial regulation, as a way to generalize their work.

On the other hand, the communications are overwhelming or excessive: financial regulation feature many complexities makes even partial transparency is of limited usefulness to the users.

This include: complexity in financial transactions and rules which apply them, and the information glut resulted from sharing the responsibility of financial regulation among different entities, such as public and private bodies, and among transnational, 
The Impact of Investors' Excessive Biased Expectations ...

Sally Mahmoud Hashem Shams

national, and sub-national entities. In other words, transparency is excessive because financial regulation concerning proposals for new rules and standards is complicated, cross sectional, and transnational. More disclosure to more people in more effective forms adds to an information glut and undermines the ability to understand what is happening (Bardley, 2011) .

It may become difficult to rely on transparency if its complexity is not remedied. Complexity in the transparency mechanism can be reduced by providing the information and suggestions and developing more adequate disclosures. Hence, the complexity may cause opacity which is difficult to be removed.

\section{7- Hypothesis Development:}

Prior literature indicated that firms with higher sensitivity to investor sentiment tend to be opaque .

$\mathrm{Yu}, 2011$ suggested the existence of the relationship between level of investors' disagreement and level of uncertainty and volatility. In the same context, Cheng et al, 2012 indicated that, earnings announcement timing (one type of earnings opacity) may be displayed by managers as a way to strategically influence firm performance. Since earnings announcement trading likely preceded investors' full evaluation of the annual report.

Consistently, Firth et al, 2015 indicated that sentiment effects are more pronounced for firms that have greater levels of earnings management, as a proxy of financial opacity, and firms that have non- clean audit reports (either qualified, adverse or disclaimer opinion), and the effect of investor sentiment is less significant for firms audited by one of the big four auditors.

Therefore, to the extent that firm pronouncement may well be associated with managerial incentives in order to window dress 
The Impact of Investors' Excessive Biased Expectations ...

Sally Mahmoud Hashem Shams

financial information in order to favorably influence the market pricing of the firm's securities, The hypothesis of this research is:

"There is a Significant Impact of Investors' Excessive Biased Expectations on Financial Opacity".

\section{8- Empirical Study:}

\section{8-1Study Population and Sample Size:}

The population consists of all listed companies in the Egyptian stock exchange. The empirical approach is based on financial and historical stock data of these listed companies.

The study investigation period ranges from January 2011 to December 2016. Financial services companies and banks are excluded because information of these firms does not have the same meaning as for non-financial firms.

The study sample is based on 83 companies listed in the Egyptian stock exchange distributed among the different sectors.

\section{8-2Constructing Research Variables:}

\section{8-2-1Constructing Investor Sentiment (Investors' Excessive Biased Expectations) Measures:}

The study investigates the impact of investor sentiment in the Egyptian stock market, the study follows prior literature of (Baker\& Wurgler, 2006, Baker and Wurgler, 2007, and Firth et al, 2015) to construct a composite investor sentiment index using principle component analysis based on three underlying indirect proxies: (1) Share market turnover (TURN), (2) (E SHARE), and (3) ( DP-NP).

a) Share Turnover (TURN): 
The Impact of Investors' Excessive Biased Expectations ...

Sally Mahmoud Hashem Shams

Building on previous studies, share turnover ratio is a meaningful proxy for investor sentiment. (Baker and stein, 2004) suggested that aggregate trading volume is a good proxy for investor sentiment. (Baker and Wurgler , 2007) indicated that market turnover, the ratio of trading volume to the number of shares listed to new york stock exchange, is a useful proxy for this concept. (Tas and Akdag, 2012) revealed that the changes of trading volume is related to investor sentiment, in particular, trading volume provides information on security prices ' movement over time. Moreover, (Baker et al; 2012) obtained market-level turnover statistics for all six markets of their study except Germany, and all markets displayed positive trend in turnover except Japan.

Share turnover ratio is a measure of stocks' liquidity, which explain the relative ease with which an investment can easily converted into cash or how easy investors can buy or sell company's' stocks in the open market.

If there are more traders or investors showing interest in a company's shares, it will give a higher turnover ratio. This reflects a case of high investor sentiment (optimism).

\section{b) E Share:}

Prior literature indicated that equity issues over total new issues is a broader measure of equity financing activity which represent the equity share of total equity and debt issues by all corporations ( Baker and Wurgler, 2006, 2007).

This study extends prior literature and use equity share ratio as another proxy for investor sentiment. Equity share ratio is the proportion of equity issues in the total issue of equity and long term debt. 
The Impact of Investors' Excessive Biased Expectations ...

Sally Mahmoud Hashem Shams

This measure can be calculated by dividing gross equity issuance by gross equity plus gross long term debt issuance.

\section{c) DP-NP}

Recent works in the field of finance indicated that dividend premium explains well the major historical trends in firm's propensity to pay dividends.

This measure indicates the log difference of the average market to book ratio of paying and non-paying firms.

\section{8-2-2 Constructing Financial Opacity Measures:}

In order to measure financial opacity three proxies are used as follows:

\section{a) Earnings Management:}

Following the recent study of Firth et al, (2015), annual discretionary accrual is calculated as the residual from modified jones model, using the underlying regression equations:

$$
\frac{\mathrm{TACC}_{j t}}{\mathrm{TA}_{j t-1}}=\mathrm{a} \frac{1}{\mathrm{TA}_{j t-1}}+\mathrm{b} \frac{\Delta \text { Sales }_{j t}}{\mathrm{TA}_{j t-1}}+\mathrm{c} \frac{\mathrm{PPE}_{j t}}{\mathrm{TA}_{j t-1}}+\mathrm{dROA}_{j t}+\varepsilon_{j t}
$$

Where TACC is the total accruals for company $\mathrm{j}$ during year $\mathrm{t}$ which represent the difference between income before extraordinary items and net cash flows from operations, TA is total assets for company $\mathrm{j}$ at the end of year $\mathrm{t}-1, \Delta$ Sales is the change in sales from the prior year, PPEjt represent: property, plant, and equipment for company $\mathrm{j}$ at the end of year $\mathrm{t}$, and ROA refers to return on assets which is net income divided by average total assets. 
The Impact of Investors' Excessive Biased Expectations ...

Sally Mahmoud Hashem Shams

Then the inclusion of the change in receivables in the following equation is the standard modification of the jones model.

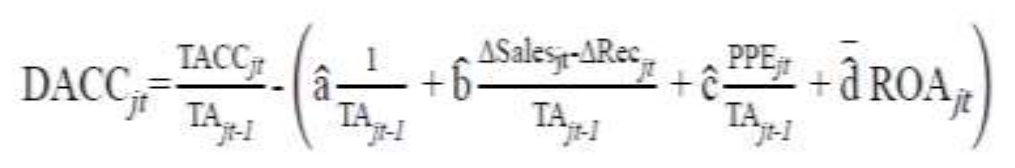

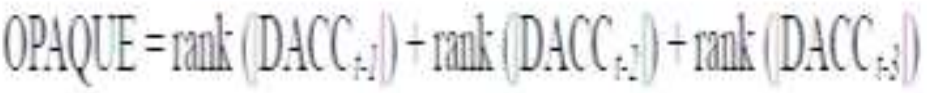

The variable OPAQUE is used as a measure of financial reporting opacity. It is calculated as the three year moving sum of the fractional ranking of the absolute value of discretionary accruals .

\section{b) Quality of Audit Firms:}

Auditors serve as independent and external monitors of managerial manipulations, and contribute in improving the quality of accounting information.

Data about the quality of audit firms have been collected from company's annual financial reports. BIG4 variable is constructed as a dummy variable that equal 1 if the company is audited by one of the Big 4 audit firms. On the other hand, it is stated as Zero, if the company is being audited by audit firm other than BIG 4.

\section{c) Audit Opinion:}

Audit opinions are classified as clean opinions (unqualified audit opinions) and non-clean opinions (qualified, adverse and disclaimer audit opinions). A dummy variable denoted OPIN is set as 1 if the company has a clean audit opinion, and zero if it 
The Impact of Investors' Excessive Biased Expectations ...

Sally Mahmoud Hashem Shams

has non-clean audit opinion.

Hence, using factor analysis (principle component analysis) the following financial opacity index is constructed:

\section{8-3 Statistical Analysis}

Table No. (2)

\section{The Relationship between Investor Sentiment and Financial Opacity}

\begin{tabular}{|l|l|c|c|}
\hline \multirow{4}{*}{ Sentiment } & Pearson Correlation & Sentiment & $\frac{\text { Financial }}{\text { opacity }}$ \\
\cline { 2 - 4 } & Sig. (2-tailed) & & .598 \\
\cline { 2 - 4 } & $\mathrm{N}$ & 412 & 0.000 \\
\hline \multirow{2}{*}{$\begin{array}{l}\text { Financial } \\
\text { Opacity }\end{array}$} & Pearson Correlation & .598 & 411 \\
\cline { 2 - 4 } & Sig. (2-tailed) & 0.000 & 1 \\
\cline { 2 - 4 } & $\mathrm{N}$ & 411 & 503 \\
\hline
\end{tabular}

Table No. (2) explains the statistical analysis of Pearson correlation between two variables, investor sentiment and financial opacity. The results suggest that, there is a moderately positive relationship between investor sentiment and financial opacity (correlation $=.598$ ) and this relationship is highly significant at $1 \%$ level $(\mathrm{Sig} .=.000)$. In other words, excessive investors' biases are positively and significantly associated with increasing the level of financial opacity. 
The Impact of Investors' Excessive Biased Expectations ...

Sally Mahmoud Hashem Shams

\section{Table No. (3)}

\section{The Impact of Investor Sentiment on Financial Opacity}

\begin{tabular}{|l|r|r|r|r|r|}
\hline & $\begin{array}{c}\text { Sum of } \\
\text { Squares }\end{array}$ & \multicolumn{1}{c|}{ Df } & $\begin{array}{c}\text { Mean } \\
\text { Square }\end{array}$ & \multicolumn{1}{|c|}{ F } & Sig. \\
\hline Regression & $\mathbf{1 3 . 5 4 0}$ & $\mathbf{1}$ & $\mathbf{1 3 . 5 4 0}$ & $\mathbf{2 2 7 . 5 3 6}$ & $\mathbf{. 0 0 0}^{\mathbf{b}}$ \\
\hline Residual & $\mathbf{2 4 . 3 3 9}$ & $\mathbf{4 0 9}$ & $\mathbf{0 . 0 6 0}$ & & \\
\hline Total & $\mathbf{3 7 . 8 7 9}$ & $\mathbf{4 1 0}$ & & & \\
\hline $\begin{array}{l}\text { a. Dependent Variable: Financial opacity } \\
\text { b. Predictors: (Constant), Sentiment }\end{array}$ & \\
\hline
\end{tabular}

Table No. (3) Suggests the impact of investor sentiment on financial opacity using ANOVA test. Investor sentiment set as an independent variable and financial opacity is set as a dependent variable. Results represent evidence on the significant effect of investor sentiment on financial opacity at $1 \%$ significance level. Interestingly, companies with greater financial opacity are more affected by investor sentiment than companies with less financial opacity.

\section{9-Conclusion, Findings and Recommendations:}

\section{9-1Conclusion:}

Opacity of accounting numbers derived from managers' incentives to manipulate earnings, Lack of fiscal clarity (the accounting standards are either loose or just bad, and the enforcement is lax), Lack of transparency, inadequate accounting rules and auditing confusion, these actions allow firms to 
The Impact of Investors' Excessive Biased Expectations ...

Sally Mahmoud Hashem Shams

withhold losses and result in asset mispricing and lead to more pronounced financial crisis.

The lack of accounting information (financial opacity) may be exploited by managers to pursue their personal agenda, or to appropriate part of the stakeholders. Thus, only when there is good accounting regime in the form of lower financial opacity, these opportunistic behaviors could be minimized. Accounting quality which is the opposite of accounting opacity predisposes a good climate for accountability and monitoring of opportunist's actions.

The level of accounting is a direct implication of the level of corruption in any country. One apparent explanation of the lower accounting quality level is the high level of financial opacity.

Studies have shown that financial opacity leads to crash risks-i.e. the severe price drops in the following periods.

Avery important concern is that how opaque or uninformative investors perceive reported accounting numbers to be.

\section{9-2Findings:}

Results represent evidence on the significant influence of investors' biased expectations on the opacity of financial reporting at $1 \%$ significant level.

Interestingly, companies with greater degree of financial reporting opacity are more affected by investor sentiment and excessive biased expectations of investors than other companies that have transparent financial reports.

Results also imply that, in periods of investors' optimism, managers may alter firms' financial outcomes and leading to greater financial opacity. Managers may manipulate financial 
The Impact of Investors' Excessive Biased Expectations ...

Sally Mahmoud Hashem Shams

numbers in order to achieve their incentives and portray their firms in a more favorable picture to attract more investors in the stock market.

On the other hand, in periods of pessimism, managers' opportunistic actions through financial opacity are decreased.

\section{9-3Recommendations:}

There is a need for increased attention from external auditors to mitigate managerial incentives to manipulate earnings (either by overstating or understating it) and to report opportunistic earnings numbers during periods of high investor sentiment.

Regulatory bodies should consider greater scrutiny of financial reporting in order to reduce financial market uncertainty.

\section{Bibliography:}

\section{A- Journals}

1. Baker M., and F., Wurgler.2007. Investor Sentiment in the Stock Market. Journal of Economic Perspectives. 21(2): 129151

2. Baker, M. and J., Stein.2004. Market Liquidity as a Sentiment Indicator. Journal of Financial Markets. 7: 271-299

3. Baker, M., and J.,Wurgler. 2006. Investor Sentiment and the Cross Section of Stock Returns. Journal of Finance. 61: 16451680

4. Baker, M., J., Wurgler, and Y., Yuan. 2012. Global, Local, and Contagious investor sentiment. Journal of Financial Economics. 104(2):272-287

5. Berger, D., and Turtle, H., J., 2012. Cross-Sectional Performance and Investor Sentiment in a Multiple Risk Factor Model. Journal of Banking and Finance. 36: 1107-1121 
The Impact of Investors' Excessive Biased Expectations ...

Sally Mahmoud Hashem Shams

6. Bushman, R., M., and A., J., Smith .2003. Transparency, Financial Accounting Information, and Corporate Governance. FRBNY Economic Policy Review. 65-87

7. H., M., Salteh, and A., Babazadeh .2012. The Effect of Opacity of the Financial Reports on Volatility of Stock Return: Evidence from Tehran Stock Exchange. J. Basic. Appl. Sci. Res. 2 (4): 3844- 3852

8. Houqe, M. N., T. V. Zijl, K., Dunstan, and A., W., Karim. 2012. The Effect of IFRS Adoption and Investor Protection on Earnings Quality Around the World. The International Journal of Accounting. 47 (3): 333- 355

9. Tas, O., and O., Akdag, 2012. Trading Volume Trend as the Investors' Sentiment Indicator in Istanbul Stock Exchange. Dogus Universitesi Dergisi. 13( 2) : 290-300

10.Yu, J., 2011. Disagreement and Return Predictability of Stock Portfolios. Journal of Financial Economics. 99:162-183

\section{$\underline{\text { B-Working Papers }}$}

1. 2011. The Role of Transparency in Financial Services Reform Presentation to Group of Experts on Banking Issues (GEBI). http://www.transparencyinternational.eu

2. Bank, M., and J., Brustbauer. 2014. Investor Sentiment in Financial Markets. Working Paper

3. Bradley, C. 2011 .Transparency is The New Opacity: Constructing Financial Regulation after the Crisis. Working paper

4. Cahan , S., F., C. Chen and N.H. Nguyen. 2013. Media Sentiment, Investor Sentiment and Stock Price Sensitivity to Earnings. Working Paper

5. Cheng and et al, 2012. Cash Flows, Earnings Opacity and Stock Price Crash Risk. Working Paper 
The Impact of Investors' Excessive Biased Expectations ...

Sally Mahmoud Hashem Shams

6. Dickinson B., and W., Hu. 2015. Sentiment Analysis of Investor Opinions on Twitter. Social Networking published online in SciRes. http:// wwW.scrip.org/journal /sn

7. Firth, M., A., and K., P., Wong, and M., S., Wong. Corporate Transparency and the Impact of Investor Sentiment on Stock Prices. Working Paper, Lingnan University

\section{C-Dissertations:}

1. Cohen D.A, 2004. Quality of Financial Reporting Choice: Determinants and Economic Consequences. Dissertation 